Zeszyty Naukowe Szkoły Głównej Gospodarstwa Wiejskiego

Ekonomika i Organizacja Gospodarki Żywnościowej nr 115, 2016: 127-139

Joanna Chudzian

Wydział Nauk Ekonomicznych

Szkoła Główna Gospodarstwa Wiejskiego w Warszawie

\title{
Wpływ czynników ekonomicznych na zachowania zrównoważone konsumentów żywności
}

\section{Wstęp}

Jak wskazują badania naukowców europejskich [Jensen i Sandoe 2002, Grunert 2005, Verbeke 2006, Zalega 2013], na skutek serii kryzysów środowiskowych, społecznych i gospodarczych społeczeństwo europejskie staje się coraz bardziej krytyczne wobec jakości i bezpieczeństwa żywności. Równocześnie $\mathrm{z}$ tym zjawiskiem wzrasta wiedza konsumencka dotycząca zmian w zakresie środowiska i w tej konsekwencji zrozumienie dla koncepcji zrównoważonego rozwoju (zarówno w zakresie zrównoważonej produkcji jak i konsumpcji). W efekcie tych zmian obserwuje się trend dotyczący świadomego poszukiwania produktów. Według raportu BeCAUSE it Matters z 2014 roku autorstwa Global Havas PR Collective 70\% badanych chciałoby kupować produkty marek, które pozwalają na wspieranie zrównoważonego rozwoju, a $22 \%$ dokonuje wyborów jednych marek nad drugimi z uwzględnieniem odpowiedzialności społecznej i środowiskowej.

Zrównoważona konsumpcja (ang. sustainable consumption) wywodzi się od pojęcia zrównoważonego rozwoju (ang. sustainable development) i definiowana jest jak „optymalne, świadome i odpowiedzialne korzystanie z dostępnych zasobów naturalnych, dóbr i usług na poziomie jednostek, gospodarstw domowych, wspólnot i społeczności lokalnych, środowisk biznesowych, samorządów terytorialnych, rządów krajowych i struktur międzynarodowych, zgodnie z zasadami zrównoważonego rozwoju" [Boć i in. 2000). Celem konsumpcji zrównoważonej jest zatem zaspokojenie potrzeb i podniesienie jakości życia w wymiarze lokalnym i globalnym, przy jednoczesnym przestrzeganiu praw człowieka i praw pracowniczych, uwzględnianiu możliwości zaspokojenia potrzeb innych ludzi, 


\section{8}

w tym przyszłych pokoleń, równocześnie z zachowaniem i odtworzeniem dla nich kapitału przyrodniczego. W stosunku do konsumpcji zrównoważonej często wymienia się terminy: świadoma konsumpcja, etyczna konsumpcja czy odpowiedzialna konsumpcja, jednak nie uwzględniają one wszystkich aspektów podanych w definicji. Kiełczewski [2008] wskazuje iż, aspekty, w których należy rozpatrywać konsumpcję zrównoważoną, to w szczególności aspekt: ekonomiczny, ekologiczny, społeczny, psychologiczny, demograficzny, przestrzenny czy intertemporalny.

Na rynku żywności konsumpcja zrównoważona ma szczególne znaczenie. Badania zlecone przez Komisję Europejską i przeprowadzone w ramach EIPRO i EEA w 25 krajach Unii Europejskiej wykazały, że żywność i napoje, obok transportu prywatnego oraz ogrzewania mieszkania, odpowiadają za $70-80 \%$ wpływów na środowisko oraz pochłaniają $60 \%$ wydatków konsumpcyjnych gospodarstw domowych.

Wśród zachowań konsumenckich wpisujących się w nurt zrównoważonej konsumpcji żywności badacze obserwują w szczególności takie zachowania jak (Słaby 2006, Mizera 2008, Salleh i Ali 2010, Pearson i in. 2011, Szul 2012, Tapia-Fonllem, i in. 2013, Davies i in. 2014, Szubska-Włodarczyk 2014, Wasilik 2014, Welch i Warde 2015):

- skłonność do zakupu: żywności świeżej, żywność lokalnej (etnocentryzm konsumencki, locavorism), żywności ekologicznej,

- gotowość do uwzględniania w wyborach konsumenckich warunków pracy w przypadku wybieranych produktów oraz czynników wpływających na wykorzystanie zasobów naturalnych,

- skłonność do ograniczania ilości kupowanej żywności - dekonsumpcji, racjonalizacji,

- dążenie do niezależności żywnościowej.

Ważnymi czynnikami warunkującymi wybór zrównoważonych produktów spożywczych są czynniki ekonomiczne, a wśród nich w szczególności:

- obiektywna i subiektywna ocena sytuacji finansowej,

- cena produktu mierzona jako gotowość do zapłacenia więcej za produkty zrównoważone (WTP - ang. willingness to pay),

- przewidywania dotyczące sytuacji finansowej w przyszłości.

W przypadku oceny sytuacji finansowej badania pokazują, iż u osób u których wzrasta subiektywna ocena sytuacji finansowej, rośnie skłonność do uwzględniania aspektów zrównoważonych w zakupach [Kiełczewski 2008]. $\mathrm{Z}$ kolei gotowość do zapłacenia więcej za produkty zrównoważone żywnościowe ma szczególne znaczenie w przypadku zakupu produktów lokalnych i organicznych [Vechcio i Annunziata 2015, de-Magistris i Gracia 2016]. Ponadto osoby pozytywnie oceniające swoją sytuację finansową w przyszłości są bardziej 
skłonne do wybierania produktów premium [Furnham 1984] Można więc domniemywać, że w przypadku żywnościowych produktów zrównoważonych te zależności będą podobne.

Celem artykułu jest określenie, w jakim stopniu czynniki ekonomiczne warunkują zachowania konsumentów w odniesieniu do zachowań odpowiedzialnych na rynku żywności.

\section{Metody badań}

W celu weryfikacji postawionych hipotez, przeprowadzono badanie własne z wykorzystaniem kwestionariusza ankiety. Kwestionariusz do oceny skłonności do zachowań odpowiedzialnych zawierał 7 skal o wysokiej rzetelności, a każda ze skal od 2 do 9 stwierdzeń opracowanych na skali Likerta:

- podskala 1: żywność zrównoważona - lokalna: 4 stwierdzenia, $\alpha=0,620$,

- podskala 2: żywność zrównoważona - świeża: 6 stwierdzeń, $\alpha=0,388$,

- podskala 3: żywność zrównoważona - ekologiczna: 4 stwierdzenia, $\alpha=0,779$,

- podskala 4: warunki pracy: 5 stwierdzeń, $\alpha=0,627$,

- podskala 5: zasoby naturalne: 10 stwierdzeń, $\alpha=0,856$,

- podskala 6: dekonsumpcja: 2 stwierdzenia, $\alpha=0,369$,

- podskala 7: niezależność żywnościowa: 4 stwierdzenia , $\alpha=0,516$.

Rzetelność całego kwestionariusza ze skalami wniosła $\alpha=0,895$. Wszystkim stwierdzeniom na skali Likerta przypisana została identyczna kafeteria odpowiedzi, co uczyni je zestawem skal porządkowych. Każde stwierdzenie konsument oceniał według stopnia zgodności ze swoim zachowaniem. W kwestionariuszu stwierdzenia zostały umieszczone w sposób losowy, a dodatkowo w przypadku części z nich zastosowano inwersję.

Dodatkowo w kwestionariuszu uwzględniono pytania dotyczące czynników ekonomicznych (ocena teraźniejszej i przyszłej sytuacji finansowej, gotowość do zapłacenia więcej za produkty zrównoważone - WTP), z których został skonstruowany wskaźnik opisany w części wynikowej oraz czynników demograficznych.

\section{Wyniki badań}

Rozważana w badaniu próba złożona była z 724 osób dobranych w sposób losowy, z czego 62,3\% (451 osób) stanowiły kobiety, zaś 37,7\% (273) mężczyźni. Większość badanych pochodziła $z$ dużego miasta $(68,6 \%)$, zaś małe miasta i wieś reprezentowało odpowiednio 17,5 oraz 13,8\% respondentów. Zdecydowana większość badanych legitymowała się średnim wykształceniem - było to 
516 osób, czyli $71,2 \%$ całej próby. Dokładnie $28,5 \%$ badanych posiadało wykształcenie wyższe. W badaniu poproszono respondentów również o przedstawienie swoich preferencji żywieniowych oraz poglądów politycznych, dla których zaobserwowano $\mathrm{w}$ analizie literatury zależności $\mathrm{w}$ przypadku produktów zrównoważonych nieżywnościowych. Zdecydowana większość, (90,9\% procent próby badawczej), żywiło się w sposób tradycyjny. Spośród badanych $9,1 \%$ zadeklarowało stosowanie diety wegetariańskiej lub wegańskiej. Jeśli chodzi o preferencje polityczne, to poglądy prawicowe lub centro-prawicowe zadeklarowało odpowiednio 29 i 16,7\% respondentów. Sympatie lewicowe i centro-lewicowe wskazało $9,5 \%$ oraz $12,8 \%$ badanych. Poglądy inne od wskazanych zadeklarowało najwięcej, bo $31,9 \%$ badanej populacji.

Respondentom biorącym udział $\mathrm{w}$ badaniu zadano pytania o ich bieżąca i przewidywaną w nieodległej przyszłości sytuację ekonomiczną. Na pytanie „Jak oceniasz swoją aktualną sytuację finansową?” 18,6\% respondentów oceniło ją jako bardzo słabą lub słabą. Znaczna większość, bo aż 71,4\%, uważa swoją sytuację ekonomiczną za dobrą. Bardzo dobrze swoją aktualną sytuację finansową ocenia 9,9\% respondentów. Rozważana w badaniu populacja jest w większości optymistycznie nastawiona do swojej przyszłej sytuacji finansowej. Jedynie 3,2\% respondentów na dotyczące przewidywanej sytuacji ekonomicznej za dwa lata odpowiedziało, że gorzej niż teraz. Brak zmian w swojej sytuacji ekonomicznej przewiduje $31,1 \%$ badanych. Aż $65,7 \%$ badanej próby uważa, że w ciagu dwóch lat ich status finansowy ulegnie poprawie.

W kwestionariuszu wyróżnić można pytania odnoszące się do ekonomicznych aspektów zrównoważonej konsumpcji. Ich kombinacja, uwzględniająca inwersję niektórych pytań, stanowi wskaźnik, który w dalszej części nazywany będzie dylematem ekonomicznym (DE). Wskaźnik ten oparty jest na stwierdzeniach, które zebrane są w tabeli. Wskaźnik dylemat ekonomiczny skonstruowany został jako średnia odpowiedzi na przedstawione pytania.Wszystkie pytania z tabeli skonstruowane są na skali Likerta o zakresie $1-5$, wobec czego cały wskaźnik dylemat ekonomiczny zawiera się również w tym przedziale.

Rozkład wskaźnika dla całej badanej populacji jest zbliżony do normalnego ze średnią równą 3,06, a odpowiadający histogram wartości przedstawiony został na rysunku 1 . Widać na nim nieco wydłużony lewy ogon rozkładu, co potwierdza mediana wskaźnika przesunięta nieco w prawo do wartości 3,15. Zmierzone odchylenie standardowe wynosi 0,63 .

Zależność wartości wskaźnika dylemat ekonomiczny zestawiono z cechami demograficznymi badanej populacji. W celu jednoczesnego zobrazowania wpływu tych cech na wartości wskaźnika w wielu wymiarach zastosowano drzewo 
Tabela

Lista stwierdzeń uwzględnionych we wskaźniku dylemat ekonomiczny

\begin{tabular}{|c|l|c|}
\hline Lp. & \multicolumn{1}{|c|}{ Stwierdzenia } & Inwersja \\
\hline 1 & Zdarza mi się wybrać jabłka z zagranicy, jeśli są tańsze niż krajowe. & Tak \\
\hline 2 & $\begin{array}{l}\text { Uważam, że dla jednej osoby nie opłaca się gotować w domu. Lepiej } \\
\text { zjeść na mieście. }\end{array}$ & Tak \\
\hline 3 & Jestem skłonna/y zapłacić więcej za produkt ekologiczny. & Nie \\
\hline 4 & $\begin{array}{l}\text { Idąc na zakupy, biorę torbę wielorazowego użytku, żebym nie musiał/a } \\
\text { dodatkowo kupować reklamówek w sklepie. }\end{array}$ & Nie \\
\hline 5 & $\begin{array}{l}\text { Jestem skłonny/a zapłacić więcej za produkt żywnościowy, który został } \\
\text { wyprodukowany z poszanowaniem praw pracownika. }\end{array}$ & Nie \\
\hline 6 & Uważam, że rozwój gospodarczy jest ważniejszy niż ochrona środowiska. & Tak \\
\hline 7 & Jestem skłonna/y zapłacić więcej za produkt przyjazny środowisku. & Nie \\
\hline 8 & $\begin{array}{l}\text { Jestem skłonna/y płacić większe podatki, jeśli część środków zostanie } \\
\text { przeznaczonych na ochronę środowiska. }\end{array}$ & Nie \\
\hline 9 & $\begin{array}{l}\text { Wolę kupić mniejsze opakowanie, nawet jeśli jest droższe, bo nie lubię } \\
\text { jak się marnuje. }\end{array}$ & Tak \\
\hline 10 & $\begin{array}{l}\text { Uważam, że wyrzucanie przeterminowanej żywności to głównie strata } \\
\text { pieniędzy. }\end{array}$ & Tak \\
\hline 11 & Wolę kupić mniej droższego sera, ale lepszej jakości. & Nie \\
\hline 12 & $\begin{array}{l}\text { Wolę raz na jakiś czas iść do kawiarni na dobrą kawę niż kupować spe- } \\
\text { cjalnie ekspres do kawy. }\end{array}$ & Nie \\
\hline 13 & $\begin{array}{l}\text { Wolę mieć własny toster niż pożyczać na szybko po znajomych, kiedy } \\
\text { zachce mi się tostów, nawet jeśli będę je robić raz w roku. }\end{array}$ & Tak \\
\hline 14 & $\begin{array}{l}\text { Uważam, że ludzie robią własne przetwory głównie po to, żeby oszczę- } \\
\text { dzić pieniądze. }\end{array}$ & Tak \\
\hline 15 & $\begin{array}{l}\text { Uważam, że warto samodzielnie piec chleb, nawet jak wychodzi drożej } \\
\text { niż kupować w sklepie. }\end{array}$ & Tak \\
\hline
\end{tabular}

Źródło: Badanie własne.

regresyjne, w którym poszczególne węzły odpowiadają aspektom demograficznym, zaś w liściach znajdują się możliwie najbardziej homogeniczne względem wskaźnika dylemat ekonomiczny grupy respondentów. Uzyskane drzewo regresji przedstawione jest na rysunku 2. Jak widać, pierwszy podział występuje ze względu na płeć. Kobiety (zakodowane w badaniu wartością numeryczną 1), którym odpowiada $\mathrm{w}$ drzewie węzeł 1 , mają średnią wskaźnika na poziomie 3,158 (wobec 3,057 dla całej populacji). Dla mężczyzna (węzeł 2, kodowanie wartością 2) odpowiednia średnia wynosi 2,892 , a więc istotnie mniej (p-wartość w węźle poniżej 0,01$)$. 


\section{Rysunek 1}

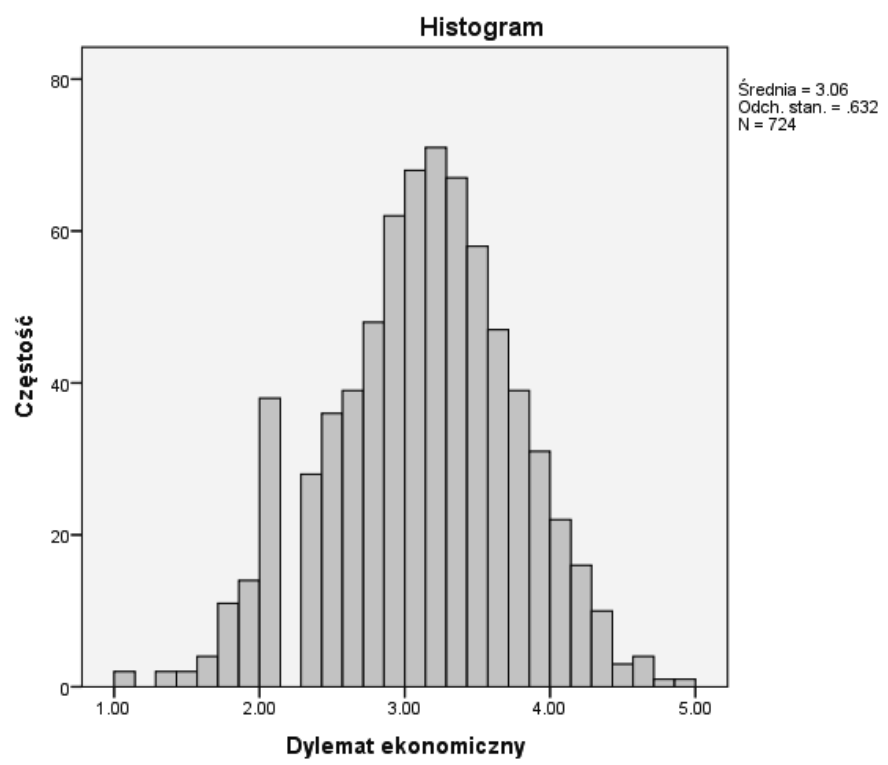

Rozkład wartości wskaźnika dylemat ekonomiczny

Źródło: Badanie własne.

Kolejny istotny podział populacji odbywa się w ścieżce odpowiadającej kobietom. Mieszkanki wsi i małych miast stanowią osobną podgrupę (węzeł 3), dla której wartość wskaźnika dylemat ekonomiczny wynosi 3,055 (a więc niemal tyle, co dla średniej w całej badanej populacji). W węźle 4 znalazły się natomiast kobiety mieszkające w dużym mieście, dla których średnia wskaźnika wyniosła aż 3,209. Warto zauważyć, że są to duże grupy, liczące odpowiednio 150 i 301 osób. Skorygowana $\mathrm{p}$-wartość dla testu w tych dwóch grupach również wskazuje na istotność obserwowanych $\mathrm{w}$ węzłach różnic średnich wartości wskaźnika (p-wartość równa 0,032 ).

We wcześniejszej części artykułu wyróżnione zostały istotne pytania dotyczące gotowości do zapłacenia więcej (WTP) za produkt ekologiczny, za produkt przyjazny środowisku oraz za produkt wytworzony z poszanowaniem praw pracowników. Odpowiadające pytaniom histogramy odpowiedzi przedstawiono na rysunkach 3-5.

Średnia odpowiedzi dla pytania dotyczącego gotowości zapłacenia więcej za produkt ekologiczny wyniosła 2,83 , zaś odchylenie standardowe 1,189 . Rozkład jest wyraźnie platokurtyczny - silnie ujemna wartość kurtozy $(-0,96)$ świadczy o zdecydowanie mniejszej koncentracji (większym wypłaszczeniu) rozłożenia odpowiedzi niż przy rozkładzie normalnym. $Z$ histogramu widać wyraźnie, że odsetek respondentów niechętnych do zapłacenia więcej za produkt ekologiczny jest większy niż wynikałoby to z rozkładu normalnego. Mała liczba badanych 
Dylemat ekonomiczny

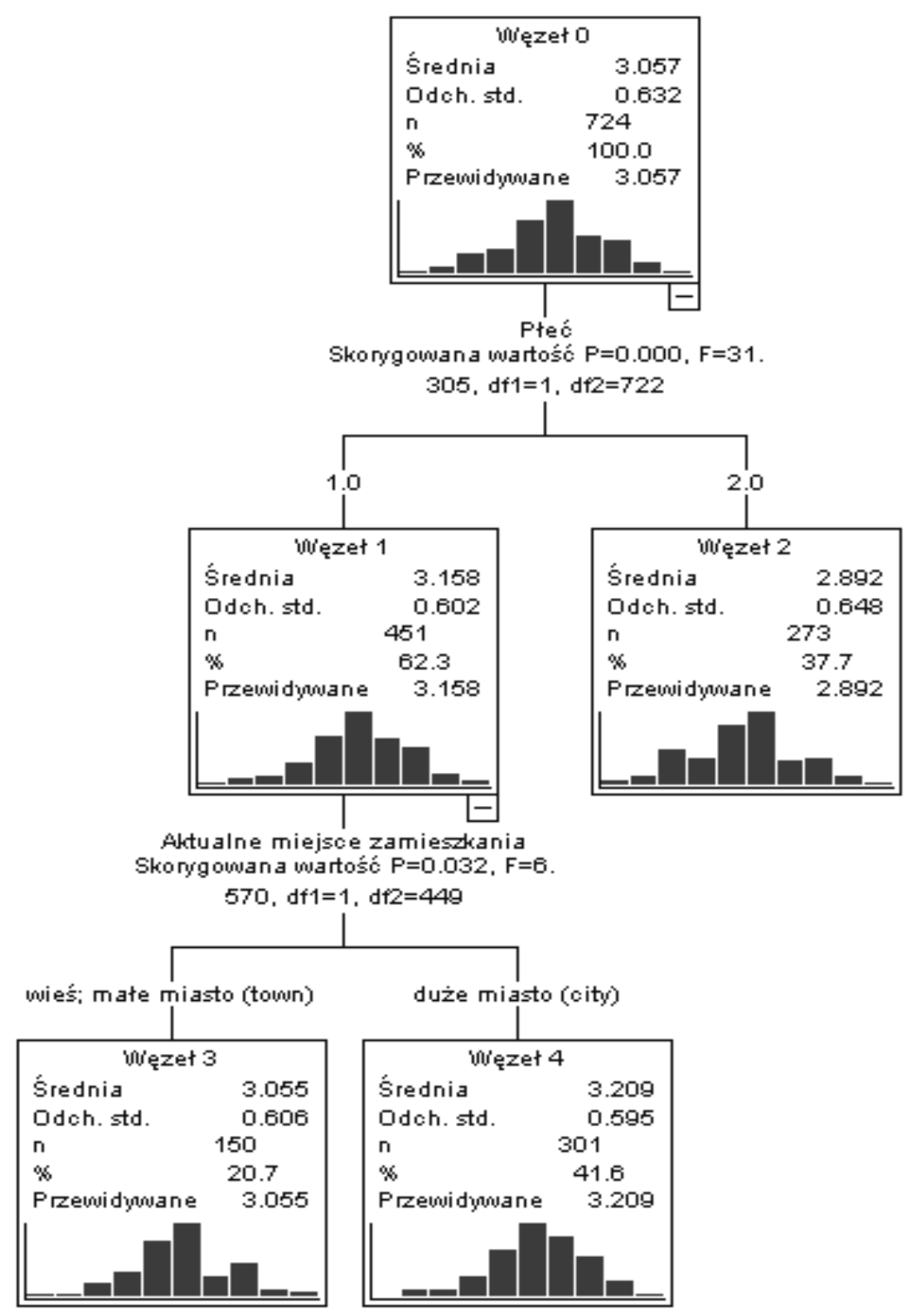

Rysunek 2

Wpływ cech demograficznych na wartość wskaźnika dylemat ekonomiczny Źródło: Badanie własne.

zdecydowanie skłonnych zapłacić więcej jest jednak niwelowana przez znaczny odsetek częściowo (,,raczej”) gotowych do przeznaczenie dodatkowych pieniędzy ze względu na ekologiczność produktu. 


\section{4}

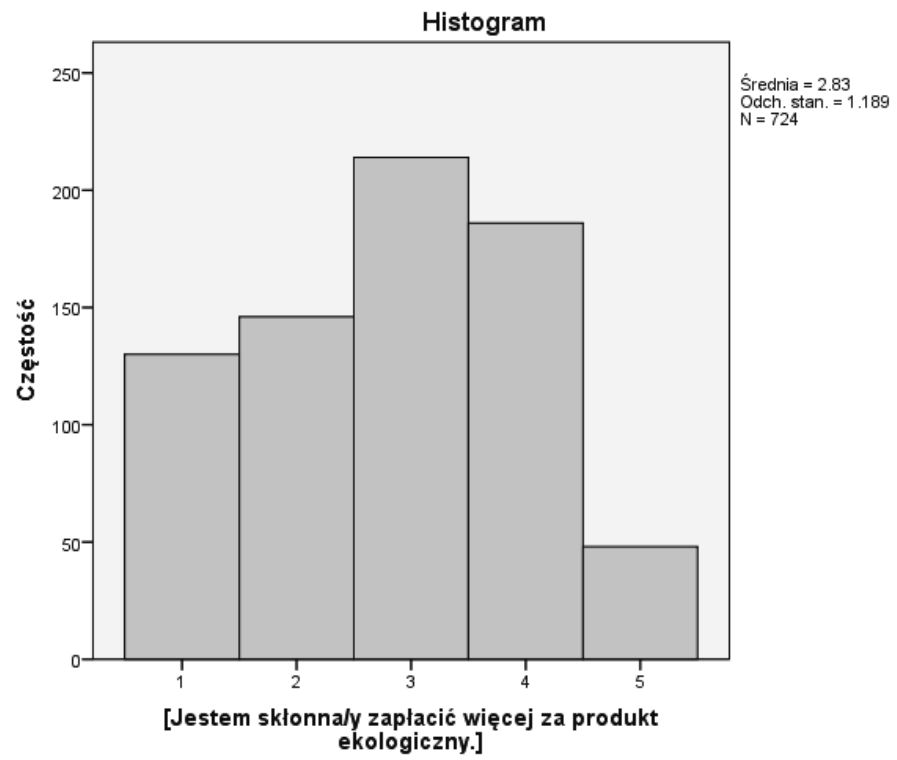

\section{Rysunek 3}

Skłonność do zapłacenia więcej za produkt ekologiczny Źródło: Badanie własne.

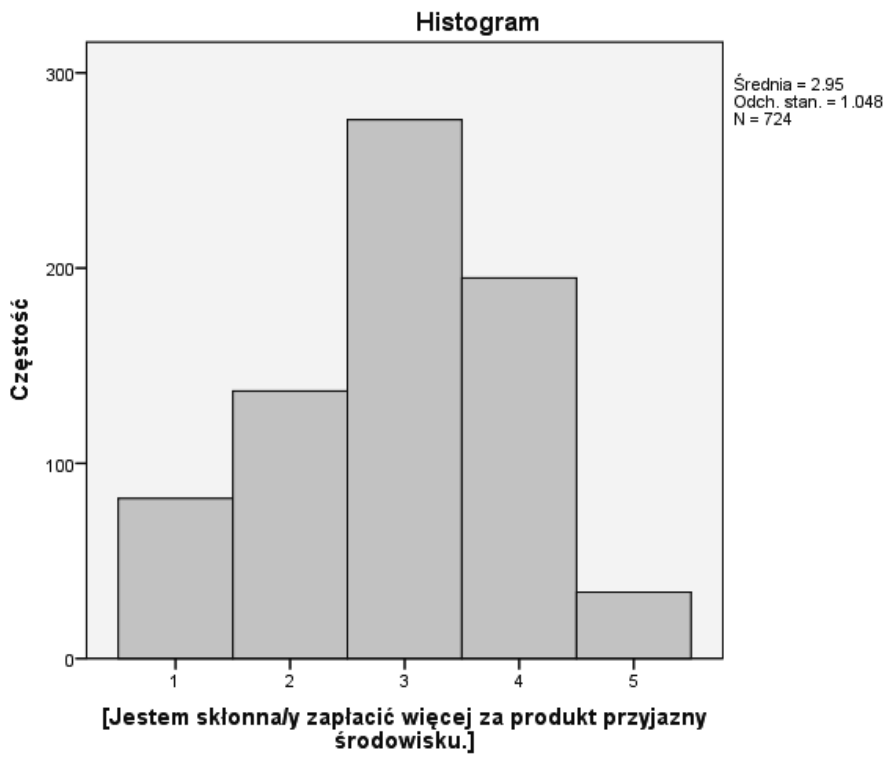

\section{Rysunek 4}

Skłonność do zapłacenia więcej za produkt przyjazny środowisku Źródło: Badanie własne. 


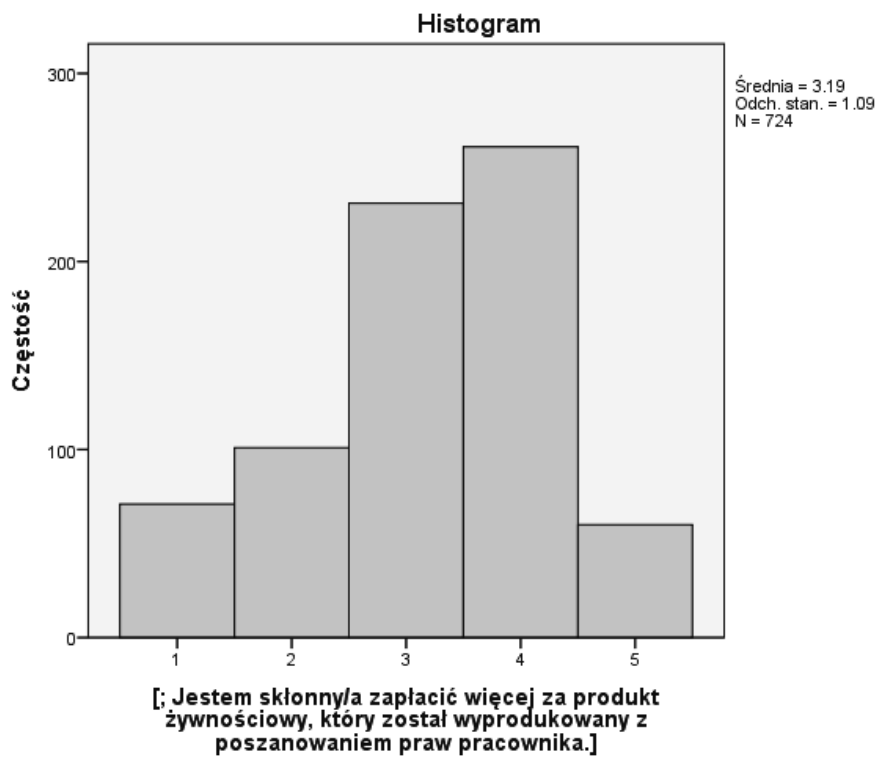

\section{Rysunek 5}

Skłonność do zapłacenia więcej za produkt żywnościowy wyprodukowany z poszanowaniem praw pracownika

Źródło: Badanie własne.

Skłonność do zapłacenia więcej za produkt przyjazny środowisku ma rozkład zdecydowanie bardziej zbliżony do normalnego o wartościach średniej równej 2,95 oraz odchyleniu standardowym 1,048. Rozkład odpowiedzi dla tego pytania jest również platokurtyczny, choć wartość kurtozy wynosi tym razem tylko $-0,546$. W tym przypadku również rzuca się w oczy mała liczba badanych zdecydowanie skłonnych zapłacić więcej oraz odpowiednio większa częściowo gotowych zapłacić więcej za produkt przyjazny środowisku.

Rozkład odpowiedzi dla pytania o skłonność do zapłacenia więcej za produkt wyprodukowany z poszanowaniem praw pracownika (rys. 5) charakteryzuje się podobnym poziomem koncentracji wartości (kurtoza równa-0,454), ale w odróżnieniu od poprzednich pytań, jest wyraźnie lewoskośny. Średnia i odchylenie dla tego rozkładu wynoszą odpowiednio 3,19 oraz 1,090.

Przedstawiony na histogramie rozkład wskazuje, że spośród trzech rozważanych czynników mogących wpływać na skłonność do wydawania większych pieniędzy, produkty żywnościowe wytworzone z poszanowaniem praw pracownika w największym stopniu tę skłonność wzmagają. Odsetek odpowiedzi zdecydowanie i częściowo negatywnych jest największy spośród trzech rozważanych pytań. Również liczba osób częściowo zdecydowanych do zapłacenia wyższej ceny jest większa niż liczba osób niezdecydowanych, co nie miało miejsca w przypadku pozostałych WTP. 
Na podstawieo przeglądu literatury zidentyfikowano potencjalne korelaty skali odpowiedzialnych zakupów zaobserwowane przez badaczy z krajów europejskich i ze Stanów Zjednoczonych i uwzględniono je w badaniu kwestionariuszowym. Poniżej zestawiono istotne związki cech społeczno-demograficznych z wynikami respondentów na skali odpowiedzialnych zakupów żywności. Uzyskane wyniki pozwalają zaobserwować następujące związki z czynnikami ekonomicznymi.

W przypadku dylematu ekonomicznego istnieje istotna zależność między jego wartością a płcią. Analiza wariancji (ANOVA) pozwala zauważyć, że dla kobiet wartość tego wskaźnika jest istotnie większa niż dla mężczyzn (odpowiednio 3,15 i 2,89) przy wartości statystyki równej $\mathrm{F}=31,305$ i p $<0,001$. Podobna analiza pozwala również wskazać na wzrost średniej wartości wskaźnika wraz ze wzrostem wielkości zamieszkiwanej miejscowości - 2,97 dla wsi i małego miasta, oraz 3,09 dla dużego miasta (przy F =2,738 i p = 0,065). Również dieta i poglądy polityczne mają związek ze średnim poziomem dylematu ekonomicznego. Osoby deklarujące dietę wegetariańską charakteryzują się istotnie wyższą średnią $(3,50)$ niż ogół badanej populacji $(3,05)$, przy wartości statystyki $\mathrm{F}=4,089 \mathrm{i} \mathrm{p}=0,003$ (ANOVA). Średnia wartość wskaźnika jest również istotnie wyższa wśród badanych deklarujących poglądy bliższe lewicowym. Poszczególne średnie mają następujące wartości: prawicowe $-2,91$, centro-prawicowe $-3,11$, centro-lewicowe $-3,09$, lewicowe $-3,20$, oraz inne $-3,08$. Wartość statystyki w tym przypadku wynosi $\mathrm{F}=4,123$ oraz $\mathrm{p}=0,003$ (ANOVA).

W przypadku gotowości do zapłacenia więcej za produkt ekologiczny analiza wariancji również wskazuje na istotnie wyższą średnią odpowiedzi w przypadku kobiet $(2,93)$ niż mężczyzn $(2,67)$, przy wartościach statystyki $\mathrm{F}=8,218$ i $\mathrm{p}=0,004$. W tym przypadku wśród osób deklarujących dietę wegetariańską średnia skłonność do zapłacenia więcej za produkt ekologiczny jest również wyższa niż w pozostałych przypadkach ( 3,55 względem 2,83 dla ogółu). Wartość statystyk dla analizy wariancji wynosi tutaj $F=3,577 \mathrm{i} p=0,007$. Bardziej skłonne do zapłacenia więcej za taki produkt są również osoby, które optymistyczniej wypowiadają się odnośnie oczekiwań co do przyszłej sytuacji finansowej. Średnie dla osób oczekujących pogorszenia, pozostania na tym samym poziomie oraz poprawy sytuacji finansowej wynoszą odpowiednio $2,17,2,78$ oraz 2,88, co daje istotne różnice według analizy wariancji przy $\mathrm{F}=4.253 \mathrm{i} \mathrm{p}=0,015$.

Gotowość do zapłacenia więcej za produkt przyjazny środowisku deklaruje, podobnie jak w poprzednim pytaniu, więcej kobiet niż mężczyzn - odpowiednio 3,11 i 2,68 (ANOVA $z$ wartościami statystyk $F=30,234$ i p $<0,001$ ). Osoby deklarujące dietę wegetariańską charakteryzują się istotnie wyższą gotowością $(3,80)$ niż ogół badanej populacji $(2,95)$, przy wartości statystyki $F=4,487$ i $\mathrm{p}=0,001$ (ANOVA). Przeciętna gotowość do zapłacenia więcej za produk- 
ty przyjazne środowisku jest również istotnie wyższa wśród badanych deklarujących poglądy bliższe lewicowym. Poszczególne średnie mają następujące wartości: prawicowe - 2,79, centro-prawicowe - 2,90, centro-lewicowe - 3,04, lewicowe $-3,20$, oraz inne $-2,99$, przy Wartości statystyki $F=2,647$ oraz $\mathrm{p}=0,032($ ANOVA).

W przypadku gotowości do zapłacenia więcej za produkt wytworzony z poszanowaniem praw pracowników różnice średnich względem płci nie są już tak duże jak dla poprzednich dwóch pytań, ale nadal są istotne. Gotowość wśród kobiet kształtuje się na poziomie 3,24 wobec 2,94 u mężczyzn. Wartość statystyki analizy wariancji wynosi $\mathrm{F}=23,607 \mathrm{i} \mathrm{p}<0,001$. Poziom wykształcenia jest ujemnie skorelowany ze średnią wartością deklarowanej gotowości do zapłacenia więcej za tego typu produkty. Osoby o wykształceniu podstawowym, średnim i wyższym deklarują średnią gotowość na poziomach 4,00, 3,23 oraz 3,09 odpowiednio, przy wartości statystyki $\mathrm{F}=2,524$ i $\mathrm{p}=0,057$ (ANOVA). Deklarowane poglądy polityczne również mają istotny wpływ na deklarowaną gotowość przy średnich wartościach dla poszczególnych grup wynoszących: prawicowe $-2,95$, centro-prawicowe $-3,34$, centro-lewicowe $-3,22$, lewicowe $-3,43$, oraz inne $-3,24$. Wartość statystyk analizy wariancji wynosi tutaj $F=4,239$ i $p=0,002$. Istotna zależność $\mathrm{w}$ przypadku tego pytania o gotowość występuje również $z$ oceną przyszłej sytuacji finansowej. Analiza wariancji wskazuje na istotnie niższą gotowość do zapłacenia więcej za produkt wytworzony z poszanowaniem praw pracownika wśród osób pesymistycznie nastawionych do przyszłej sytuacji finansowej $(2,57)$ w porównaniu z osobami oczekującymi pozostania na tym samym poziomie $(3,22)$ oraz poprawy sytuacji finansowej $(3,21)$. Wartość statystyki wynosi w tym przypadku $\mathrm{F}=3,945 \mathrm{i} \mathrm{p}=0,02$ (ANOVA).

\section{Podsumowanie}

Konsumpcja zrównoważona na rynku żywności jest rozwijającym się trendem konsumenckim i widać aktywność konsumencką we wszystkich obszarach definicyjnych zjawiska. Badania pokazują, że czynniki ekonomiczne stanowią istotną determinantę wyboru i mają znaczenie szczególnie dla niektórych grup konsumentów. Najważniejszą cechą potwierdzoną na wszystkich etapach badania jest płeć. Kobiety zdecydowanie częściej niż mężczyźni są gotowe na zapłacenie więcej za ekologiczne czy ,etyczne” produkty spożywcze. Taki rezultat nie został dotąd potwierdzony badaniami, może jednak wynikać z częstszego wśród kobiet faktu dokonywania zakupów dla gospodarstw domowych oraz większej świadomości konsumenckiej na rynku żywności. Warto jednak przyjrzeć mu się bliżej w kolejnych badaniach. 
Wyróżnione na podstawie literatury przedmiotu możliwe korelaty zachowań zrównoważonych na rynku żywności pokazały także, że skłonność do akceptacji wyższej ceny produktów zrównoważonych i większą wrażliwość na cenę obserwuje się także u osób z dużych miast, na diecie innej niż tradycyjna, osób deklarujących poglądy centrowe i lewicowe czy charakteryzujących się pozytywną oceną własnej przyszłości. Wszystkie te wyniki mogą w przyszłości posłużyć do weryfikacji specyficznego segmentu na tym rynku i z całą pewnością są warte przyjrzenia się im w postaci dodatkowych badań.

\section{Literatura}

BOĆ J., NOWACKI K., SAMBORSKA-BOĆ E., 2000: Ochrona środowiska, Wyd. Kolonia Limited, Wrocław.

DAVIES, A., FAHY, F., RAU, H., 2014: Challenging Consumption: Pathways to a More Sustainable Future, Routledge, London.

de-MAGISTRIS T., GRACIA A., 2016: Consumers' willingness to pay for sustainable food products: the case of organically and locally grown almonds in Spain, Journal of Creaner Production 118, 97-104.

FURNHAM A., 1984: Many sides to the coin: the psychology of money usage, Personality and Individual Differences 5, 501-509.

GRUNERT K.G., 2005: Food quality and safety: consumer perception and demand, European Review of Agricultural Economics 32, 3, 369-391.

JENSEN K.K., SANDOE P., 2002: Food Safety and Ethics: The Interplay between Science and Values, Journal of Agricultural and Environmental Ethics 15, 245-253.

KIEŁCZEWSKI D., 2008: Konsumpcja a perspektywy zrównoważonego rozwoju, Wyd. Politechniki Białostockiej, Białystok.

MIZERA K., 2011: Trendy w konsumpcji - w kierunku zrównoważonego rozwoju, Uniwersytet Opolski, Opole.

PEARSON D., HENRYKS J., JONES H., 2011: Organic food: What we know (and do not know) about consumers, Renewable Agriculture and Food Systems 26.2, 171-177.

SALLEH M.M., ALI S.M., 2010: Consumer's perception and purchase intentions towards organic food products, Canadian Social Science, 6.6, 119-129.

SŁABY T., 2006: Konsumpcja. Eseje statystyczne, Difin, Warszawa.

SZUBSKA-WŁODARCZYK N., 2014: Analiza popytu na produkty Sprawiedliwego Handlu, Konsumpcja i Rozwój 4 (9), 40-51.

SZUL E., 2012: Dekonsumpcja - moda czy sposób na kryzys, Nierówności Społeczne a Wzrost Gospodarczy 24, 316-328.

TAPIA-FONLLEM C., CORRAL-VERDUGO V., FRAIJO-SING B., DURÓN-RAMOS M., 2013: Assessing Sustainable Behavior and its Correlates: A Measure of Pro-Ecological, Frugal, Altruistic and Equitable Actions, Sustainability 5 (2), 711-723.

VECCHIO R., ANNUNZIATA A., 2015: Willingness-to-pay for sustainability-labelled chocolate: an experiment auction approach, Journal of Cleaner Production 86, 335-342.

VERBEKE W., 2006: Functional foods: Consumer willingness to compromise on taste for health?, Food Quality and Preference 17, 1-2, 126-131. 
WASILIK K., 2014: Trendy w zachowaniach współczesnych konsumentów - konsumpcjonizm a konsumpcja zrównoważona, Konsumpcja i Rozwój 1 (6), 66-74.

WELCH D., WARDE A., 2015: Theories of Practice and Sustainable Consumption', [w:] L. Reisch, J. Thøgersen (red.) Handbook of Research on Sustainable Consumption. Wyd. Edward Elgar Publishing, Cheltenham, 84-100.

ZALEGA T., 2013: Alternatywne trendy konsumenckie $w$ miejskich gospodarstwach domowych $w$ Polsce $w$ okresie kryzysu, Studia i Materiały Wydziału Zarządzania Uniwersytetu Warszawskiego 16, 56-78.

\section{Abstrakt}

Celem artykułu jest określenie, w jakim stopniu czynniki ekonomiczne warunkują zachowania konsumentów w odniesieniu do zachowań odpowiedzialnych na rynku żywności. Badanie opisane w artykule dotyczy wieloaspektowo definiowanej żywności zrównoważonej takiej jak: żywność ekologiczna (certyfikowana), żywność świeża, lokalna, nieprzetworzona, znakowana znakami Fair Trade itd. Wyniki potwierdzają założenia o istnieniu nowych, wyróżniających się, szczególnie w dużych miastach, trendach konsumenckich związanych z konsumpcją produktów zrównoważonych oraz dużym znaczeniu czynników ekonomicznych, w tym związanych z oceną własnej sytuacji finansowej.

Słowa kluczowe: konsumpcja zrównoważona, zachowania konsumentów, rynek żywności, gotowość do zapłacenia więcej

\section{The impact of economic factors on consumer behavior on sustainable food market}

\section{Abstract}

The aim of the paper is to determine the extent to which economic factors determine consumer behavior with respect to sustainability on food market. Research presented in the paper concerns food defined as sustainable in a multifaceted way, e.g. organic food (certified), fresh food, local food, unprocessed food or fair trade food. The results confirm assumption of the existence of new, outstanding, especially in bigger cities, consumer trends related to sustainable food consumption and significant importance of economic factors, including self-assessment of financial condition.

Key words: sustainable consumption, consumer behaviour, food market, willingness to pay 